\title{
12 \\ Can Facts Change Minds? The Case of Free Trade
}

\author{
Ethan Porter and Thomas J. Wood
}

Though the tide of false political claims can seem ceaseless, journalistic factchecks mostly achieve their objective: By and large, people who are exposed to them come to hold more factually accurate beliefs as a result. This has not always been obvious. Early attempts to study the effects of fact-checking concluded that exposure to fact-checks could spark ideologues to reject corrective information and come to hold less accurate views (e.g., Nyhan and Reifler 2010). More recent research, however, has found the opposite. Often employing far larger samples and examining a much wider array of issues (Haglin 2017; Porter, Wood, and Kirby 2018; Nyhan, Porter, Reifler, and Wood 2020; Wood and Porter 2019), this new evidence makes clear that journalists do not issue fact-checks for naught. Fact-checks can almost double the share of factually accurate responses provided by survey subjects, including when subjects are responding to a fact-check of a politician with whom they share a partisan identity (Porter and Wood 2019).

For the fact-checking industry, not to mention the cause of an informed republic, this would appear to be good news. It remains to be seen, however, if the increases in factual accuracy caused by fact-checks have downstream effects on related political attitudes. Prior work that has looked for a connection between fact-checks, factual accuracy, and policy attitude shifts have either come up empty-handed (e.g., Nyhan, Porter, Reifler, and Wood 2020; Porter, Wood, and Bahador 2019) or found that even after a fact-check has improved accuracy, exposure to a false claim still exerts influence on plenary attitudes (Thorson 2016). ${ }^{1}$ If fact-checks can increase accuracy without changing related political attitudes, what purpose do fact-checks really serve? Perhaps a more informed citizenry is a good unto itself. Scholars who write of the importance of political knowledge, however, often posit that accurate political knowledge

\footnotetext{
${ }^{1}$ In line with prior literature, we understand factual beliefs to refer to subjects' responses to questions for which there are both unambiguous accurate and inaccurate responses. Factual beliefs often pertain to empirical evidence. Meanwhile, political attitudes relate to subjects' views on policies and politicians, as well as other topics for which there are no unambiguous accurate or inaccurate responses.
} 
should affect related political behavior. Factual accuracy should help citizens hold politicians accountable, in that their accurate perceptions will help them reward and punish deserving politicians accordingly (e.g., Delli Carpini and Keeter 1996; Hochschild and Einstein 2015). Yet if fact-checks are incapable of changing attitudes toward politicians or policies, their democratic benefits may be limited.

In this chapter, we present evidence from a new attempt to understand whether fact-checks can change attitudes. The study described randomly assigns participants to treatments that strongly resemble journalistic fact-checks. Unlike Thorson (2016), we look at attitudes toward policies, not attitudes toward candidates. The tested fact-checks rebut misleading claims that, at various times, have been advanced by leaders of both parties. In style and substance, our treatments mimic the sort of journalistic fact-checks that subjects may encounter via real-world fact-checking organizations. Our fact-checks are not perfect vessels of corrective information-nor, for the sake of realism, should they be. As others before us have written (Uscinski and Butler 2013), fact-checks often evaluate ambiguous debates reductively, along a true-or-false spectrum that does not reflect the complexity of the issues at hand.

Substantively, our experiment focuses on free trade. In doing so, we contribute to a long-running debate about the role of factual accuracy in trade attitudes. Although prior scholars have focused on the role of accurate perceptions of one's own self-interest in trade attitudes (e.g., Fordham and Kleinberg 2012; Mansfield and Mutz 2009; Rho and Tomz 2017), we step back to look at the broader role that factual accuracy may play in trade attitudes. We thus connect the trade literature to the growing literature on false statements and factual corrections.

Trade beckons as an appealing domain to study in part because of recent developments in public opinion. Both parties have recently issued ambiguous, sometimes conflicting, signals about trade. The implications of such fluctuations for the fact-attitude connection are unclear. Will citizens fall back on party cues? Or will the confusion about parties' cues, and the complex nature of international trade policy, cause their attitudes to be more responsive to facts than they would be otherwise?

We conducted a multiwave survey experiment in December 2019. In the first wave, we collected key demographic data and administered an attention check. In the second wave, with invitations sent only to those who had passed the attention check, all respondents saw four misleading statements about trade, and, at random, saw from zero to four fact-checks of those same statements. Although our experiment tested misstatements that have been voiced by both parties, we did not attribute them to particular parties or politicians. At the end of this second wave, we administered Pew's trade attitude battery. 
In line with prior work, we find that fact-checks led to large improvements in factual accuracy. ${ }^{2}$ Unlike prior work, we also find that fact-checks can affect subjects' attitudes against the substantive direction of the initial false claims. To measure effects on attitudes as clearly as possible, all of the falsehoods we presented give reason to be skeptical about free trade. Corrections provoked subjects to be more supportive of free trade, across a wide range of trade attitudes and by a sizable amount. Can fact-checks change attitudes? Our evidence suggests that the answer is a qualified, "yes."

\section{Trade, Factual Accuracy, and Political Attitudes}

Some scholars assume that, when forming trade attitudes, individuals accurately suss out their economic self-interest (e.g., Scheve and Slaughter 2001, 48). The insights of behavioral economics, however-particularly insights into the limited cognitive capacity of economic actors (e.g., Thaler 1994)—make this assumption implausible. Indeed, recent work has shown that accurate perceptions of self-interest matter far less in the formation of trade preferences than outgroup attitudes and concern about the overall economic effects of trade policy (Mansfield and Mutz 2009; Mutz and Kim 2017). ${ }^{3}$

The robust debate about factual accuracy and trade attitudes has largely avoided engaging with the now-considerable literature on fact-checking. This is unfortunate, not least because many Americans are now exposed to factual political information via fact-checks (Graves 2016), but also because the role of factual accuracy in attitudes cannot be reduced to perceptions of self-interest alone. It may be the case that accurate perceptions of self-interest matter; but so, too, may accurate perceptions about a broader array of facts about trade.

If fact-checking can change attitudes about trade, it would represent a contribution to both the literatures on trade attitudes and factual accuracy. Such a finding would suggest that, first, accuracy matters for trade attitudes, and, more broadly, that fact-checks can shape attitudes. If, on the other hand, fact-checking has no effects on trade attitudes - that is, if fact-checks about trade increase accuracy without affecting related attitudes-this would suggest that the trade literature's interest in the accuracy of perceptions may be misguided.

\footnotetext{
2 In measuring factual accuracy, we are constrained by the fact-checks used. For this reason, at minimum we can understand our fact-checks as causing people to increase their agreement with the fact-check.

3 Although concerns about the narrowness of this conception of self-interest remain (Fordham and Kleinberg 2012), the position of Rho and Tomz (2017, S87) is stark: "the selfishness of policy preferences should no longer be treated as a self-evident axiom."
} 
The randomized provision of fact-checks also offers a methodological advantage. It is difficult to randomly vary the accuracy of perceptions of self-interest, except in laboratory games with limited external validity (e.g., dictator games). By setting aside questions about self-interest and looking at more common journalistic approaches to fact-checks, we can gain leverage on the broader question of the relationship between accuracy and attitudes while achieving a modicum of realism.

Our interest in using free trade is also motivated by recent developments in the U.S. trade debate. Trade stands out as an issue about which both parties have issued conflicting signals. In 2016, Donald Trump's campaign for the presidency upended both parties' positions on free trade (Sides, Tesler, and Vavreck 2019). Mass preferences often fall in line with signals issued by party leaders. Trade is no exception. Figure 12.1 displays attitudes toward trade by party since 2009 .

What might the gyrations depicted in the figure mean for the fact-attitude relationship? The free-trade debate is highly technical, involving trade-offs and economic indicators that may be beyond the reach of many citizens. Many scholars have noted the strong correlation between education and trade attitudes (e.g., Fordham and Kleinberg 2012; Mutz 2018). With this in mind, citizens may disregard the information provided by facts and fall back on recent party cues to which they have been exposed. It is also possible that the ambiguous partisan signals about trade may themselves be the source of subjects' confusion. Facts may appear appealingly less ambiguous, and less demanding, than sorting through the mixed partisan cues on the issue, causing subjects' attitudes to be more responsive to the facts than they are otherwise. Even if fact-checks improve accuracy, however, there is no guarantee that attitudes will move in the direction implied by the fact-checks. In an investigation of the link between facts and attitudes, Thorson (2016) finds that effectively fact-checked misstatements about political candidates still shape attitudes toward the candidates in the direction of the initial falsehood. Our experiment is meant to measure whether the exogenous introduction of facts can persuade subjects not just to become more accurate, but to change their attitudes in the direction implied by the facts.

\section{Experimental Design}

Our experiment was administered over two waves on Amazon's Mechanical Turk service. ${ }^{4}$ In the first wave, we gathered subjects' demographic information,

\footnotetext{
4 As Nyhan, Porter, Reifler, and Wood (2020) show, fact-check treatment effects observed on Mechanical Turk correspond closely to fact-check treatment effects observed on more representative samples.
} 
In general, do you think that free trade agreements between the U.S. and other countries have been $a_{-}$for the United States?

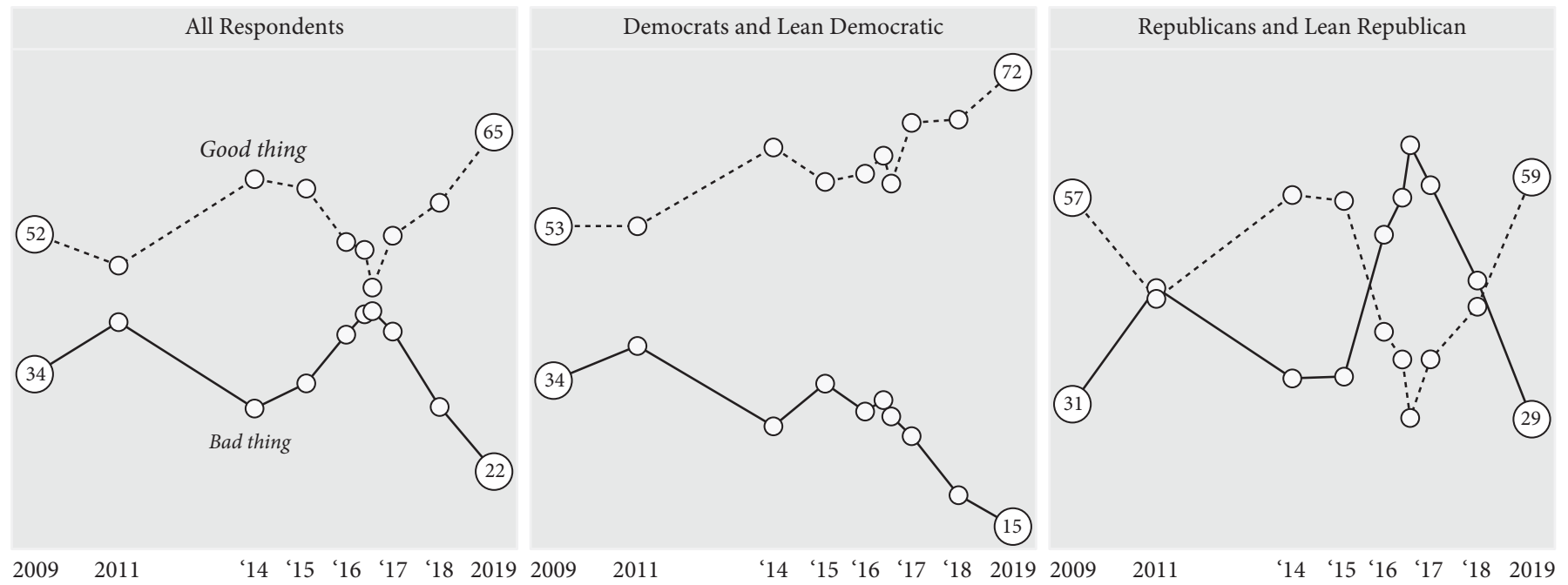

Figure 12.1. Trade attitudes, overall and by partisanship, 2009-2019. Labeled points indicate first and last estimate from each time series. Data are drawn from Pew Research Center (Silver 2019). 
including their ideological and partisan preferences, and administered an attention check. After a one-week washout period, we recontacted all subjects who had passed the attention check, inviting them to complete a supposedly unrelated survey. We then randomly assigned subjects to read from zero to four fact-checks of trade-related misstatements. All subjects were asked whether they agreed with the substantive claim advanced by each misstatement. Agreement with the misstatement was measured on a scale of one to seven, with responses ranging from "Strongly disagree" to "Strongly agree."

We aimed to test misstatements that could be said to have been advanced at various times by members of both parties. Our misstatement items concerned wages, Chinese ownership of U.S. debt, manufacturing jobs, and the definition of a trade deficit. For no misstatement did we explicitly attribute the misstatement to a politician or political party.

Crucially, we only tested false claims that could reasonably be said to cast doubt concerning free trade. If we had tested a mishmash of pro- and anti-free trade false claims, we would not have been able to draw clear conclusions about the possibility that corrections can shape attitudes. By only providing facts that comport with a single policy direction, in favor of trade liberalization, we can better estimate the relationship between factual corrections and relevant attitudes. That being said, while important for our research design, the uniform normative thrust of the misstatements and fact-checks is a limitation of our study that we will discuss later.

The bipartisan roots of our tested misstatements are vividly illustrated by comments offered about the Chinese share of U.S. debt. Mitt Romney, the 2012 Republican presidential nominee, once asserted: "I'm going to look at every federal program and I'll ask this question: 'Is a program so critical it's worth borrowing money from China to pay for it?' And if it doesn't pass that test, I'm going to eliminate that program." Making a similar point, when campaigning for President, Barack Obama said: “The way [President George W. Bush] has done it over the last eight years is to take out a credit card from the Bank of China in the name of our children, driving up our national debt ... That's irresponsible." Both claims make implications about the share of Chinese ownership of U.S. debt that are clearly contradicted by Treasury data. ${ }^{5}$ As we showed in a prior study (Wood and Porter 2019), fact-checks of these statements can drive subjects to more accurate assessments of the Chinese share of U.S. debt, even when they were exposed to the misstatement made by their copartisan.

5 In 2019, the Chinese government and Chinese investors hold less than $5 \%$ of outstanding U.S. treasuries. (U.S. Treasury Department 2020). 
Similarly, President Trump, a Republican, and Bernie Sanders, at the time a leading candidate for the Democratic Party's nomination, have advanced complementary obfuscating claims about wages. Trump once said: "The middle-class has worked so hard, are not getting the kind of jobs that they have long dreamed of-and no effective raise in years. Many of the great jobs that the people of our country want are long gone, shipped to other countries ... Wages in our country are too low, good jobs are too few" (Luhby 2015). Sanders asserted: "What we have seen is that while the average person is working longer hours for lower wages, we have seen a huge increase in income and wealth inequality" (Sanders 2011). In contrast, by several measures of the U.S. Bureau of Labor Statistics (BLS), wages, including manufacturing wages, have risen.

Evidence of the bipartisan nature of our tested claims also can be found regarding the manufacturing item. Sanders has said: "When we talk about the collapse of the middle class, it is important to also recognize the fact that, for young workers, for example, when we had a manufacturing base in America in the 1940s, 1950s, 1960s, you could graduate high school and go out and get a job in a factory" (Sanders 2011). Meanwhile, President Trump has said: "I don't think anybody makes television sets in the United States anymore. I don't want to order from South Korea. I want to order from here. I talk about it all the time. We don't make anything anymore" (Fox News 2015). Although not literally identical, the statements both make claims about long-term declines in American manufacturing that are at odds with BLS evidence.

To synthesize these claims about manufacturing into a misstatement, we devised the following: "Decades of wasteful trade policy has destroyed the U.S. manufacturing sector. There are fewer manufacturing jobs now than there were before the Great Recession. We don't make things anymore." As a correction, we offered: "This is untrue. According to the Bureau of Labor Statistics, U.S. manufacturing jobs have increased for the last eleven straight years. U.S. manufacturing exports are also at multidecade highs." (As we discuss later, by design these corrections do not attend to the many empirical reasons to be skeptical of free trade, including but not limited to its effects on manufacturing.)

Across items, all subjects assigned to see a correction for a particular item were told "This is untrue." The correction then followed. All misstatements, corrections, survey items and sources for the corrections can be found in Table 12.1. In formulating misstatements, we did not isolate the factually misleading claims. Instead, to increase realism, we designed items that contained the falsehood in question as well as the political rhetoric that might accompany it. For example, when formulating the misleading claim about manufacturing, we ended with a version of Trump's claim that appeared above: "We don't make things anymore." 
Table 12.1. Treatments, corrections, and survey items. Each respondent saw either the misstatement, or the misstatement and the correction, for each issue. Afterward, each respondent was asked the survey item in the third row.

\begin{tabular}{|c|c|c|c|c|}
\hline & Workers' Wages & U.S. Debt to China & U.S. Manufacturing Jobs & U.S. Trade Deficit \\
\hline Misstatement & $\begin{array}{l}\text { The pay and conditions } \\
\text { for working people in } \\
\text { the U.S. economy have } \\
\text { been devastated by free } \\
\text { trade agreements with } \\
\text { poor countries. American } \\
\text { workers have been made } \\
\text { to compete with overseas } \\
\text { workers who are paid } \\
\text { dollars per day; or risk } \\
\text { losing their jobs altogether. }\end{array}$ & $\begin{array}{l}\text { The United States is } \\
\text { dangerously in debt to } \\
\text { China. It holds almost all } \\
\text { of our debt. At any point, } \\
\text { China can foreclose on } \\
\text { our debt, and we'd be at its } \\
\text { mercy. }\end{array}$ & $\begin{array}{l}\text { Decades of wasteful trade } \\
\text { policy has destroyed } \\
\text { the U.S. manufacturing } \\
\text { sector. There are fewer } \\
\text { manufacturing jobs now than } \\
\text { there were before the Great } \\
\text { Recession. We don't make } \\
\text { things anymore. }\end{array}$ & $\begin{array}{l}\text { The U.S. trade deficit with China } \\
\text { is more than } \$ 400 \text { billion per year. } \\
\text { That's like we're losing } \$ 400 \text { billion } \\
\text { every year. A business couldn't } \\
\text { survive that, and neither can our } \\
\text { country. }\end{array}$ \\
\hline Correction & $\begin{array}{l}\text { This is untrue. According } \\
\text { to the Bureau of Labor } \\
\text { Statistics, US salaries } \\
\text { and hourly wages have } \\
\text { consistently increased for } \\
\text { decades, even adjusting for } \\
\text { inflation. Manufacturing } \\
\text { workers are among the } \\
\text { highest paid U.S. workers. } \\
\text { (United States Bureau of } \\
\text { Labor Statistics, 2020) }\end{array}$ & $\begin{array}{l}\text { This is false. According } \\
\text { to the Department of the } \\
\text { Treasury, China holds less } \\
\text { than } 10 \% \text { of U.S. debt. Over } \\
\text { two-thirds of U.S. debt is } \\
\text { held by the Social Security } \\
\text { Administration. The United } \\
\text { States currently pays } \\
\text { historically low interest rates } \\
\text { on its debt. (United States } \\
\text { Treasury Department, 2020) }\end{array}$ & $\begin{array}{l}\text { This is untrue. According } \\
\text { to the Bureau of Labor } \\
\text { Statistics, U.S. manufacturing } \\
\text { jobs have increased for the } \\
\text { last eleven straight years. } \\
\text { U.S. manufacturing exports } \\
\text { are also at multidecade highs. } \\
\text { (United States Bureau of } \\
\text { Labor Statistics, 2020) }\end{array}$ & $\begin{array}{l}\text { This is untrue. A } \$ 400 \text { billion } \\
\text { deficit is not a loss-it reflects the } \\
\text { payment for the goods and services } \\
\text { American consumers and businesses } \\
\text { buy from China. In exchange, we } \\
\text { received } \$ 400 \text { billion worth of TVs, } \\
\text { computers, appliances, business } \\
\text { services, and capital equipment. } \\
\text { (U.S. International Trade in Goods } \\
\text { and Services, 2020). }\end{array}$ \\
\hline Survey Item & $\begin{array}{l}\text { U.S. workers' pay is at an } \\
\text { all-time low. }\end{array}$ & $\begin{array}{l}\text { China holds the majority of } \\
\text { U.S. debt }\end{array}$ & $\begin{array}{l}\text { The U.S. manufacturing } \\
\text { sector has been steadily losing } \\
\text { jobs over the last decade. }\end{array}$ & $\begin{array}{l}\text { The trade deficit with China is a sum } \\
\text { of money we pay to China, for which } \\
\text { we receive nothing in return. }\end{array}$ \\
\hline
\end{tabular}


To see how all this worked in detail, consider our approach to falsehoods related to Chinese ownership of U.S. debt. The misstatement read:

"The United States is dangerously in debt to China. It holds almost all of our debt. At any point, China can foreclose on our debt, and we'd be at its mercy."

The false claim - that China "holds almost all of our debt"-appears in the middle of the item, bracketed between sentences echoing common political rhetoric. Subjects randomly assigned to see a correction to this issue then saw the following:

"This is false. According to the Department of the Treasury, China holds less than $10 \%$ of U.S. debt. Over two-thirds of U.S. debt is held by the Social Security Administration. The United States currently pays historically low interest rates on its debt."

The political rhetoric surrounding the initial false claim is unaddressed. Instead, respondents are presented with information that only counters the inaccurate claim about Chinese ownership of debt. The wording of the factual outcome question follows a similar approach. All subjects were asked whether they agreed or disagreed with the statement that "China holds the majority of U.S. debt."

To measure attitudes toward trade, we relied on the six-question trade attitudes battery that the Pew Research Center has used to measure attitudes toward freetrade agreements (e.g., Jones 2018). The questions ask whether "free trade is a good thing;" if respondents believe their families have been helped or harmed by free trade; whether free trade affects prices; whether trade affects wages; whether trade creates jobs; and whether trade helps or harms the overall U.S. economy. Scales differ for each question. The full text for each item, and the format of the related survey responses, are available in Table 12.2. As we discuss below, this is an imperfect battery, because several questions can be construed as measuring factual beliefs as much as attitudes. However, one question, on whether free trade is a "good thing," contains nothing that can be construed as informational. We now turn to examining effects on factual accuracy and attitudes.

\section{Results}

To test for the independence between pretreatment covariates and treatment assignment, we report the pretreatment composition of those respondents who had seen one or fewer corrections, two corrections, or three or more corrections. Table 12.3 reports both the composition of two waves, overall and by pretreatment characteristics. The next three columns in Table 12.3 report the Wave 2 composition, by column percentages, within each level of correction exposure. To assist in the interpretation of this subtable, and test for the success of the 
Table 12.2. Trade policy attitudes. These items are taken from Pew Center's trade policy polls.

\begin{tabular}{|c|c|}
\hline Survey Item & Response Format \\
\hline $\begin{array}{l}\text { In general, do you think free-trade } \\
\text { agreements between the United States and } \\
\text { other countries have been a good thing or a } \\
\text { bad thing for the United States? }\end{array}$ & Good thing/Bad thing/Don't know \\
\hline $\begin{array}{l}\text { Thinking about the financial situation of you } \\
\text { and your family-do you think free-trade } \\
\text { agreements have helped, probably helped, } \\
\text { probably hurt, or definitely hurt the financial } \\
\text { situation of you and your family? }\end{array}$ & $\begin{array}{l}\text { Definitely helped/Probably helped/ } \\
\text { Neither/Probably hurt/Definitely } \\
\text { hurt/Don't know }\end{array}$ \\
\hline $\begin{array}{l}\text { Do you think free-trade agreements make } \\
\text { the price of products sold in the United States } \\
\text { higher, lower, or do not make a difference? }\end{array}$ & $\begin{array}{l}\text { Higher/Lower/Not a difference/Don't } \\
\text { know }\end{array}$ \\
\hline $\begin{array}{l}\text { Do free-trade agreements create jobs in the } \\
\text { United States, lead to job losses, or not make } \\
\text { a difference? }\end{array}$ & $\begin{array}{l}\text { Create jobs/Reduce jobs/ Not a } \\
\text { difference/ Don't know }\end{array}$ \\
\hline $\begin{array}{l}\text { Do free-trade agreements make the } \\
\text { American economy grow, slow the economy } \\
\text { down, or not make a difference? }\end{array}$ & $\begin{array}{l}\text { Make the economy grow/Make the } \\
\text { economy slow down/Not a difference/ } \\
\text { Don't know }\end{array}$ \\
\hline
\end{tabular}

randomization, the final column reports the $\chi^{2}$ statistic associated with the correction exposure data and the p-value associated with this statistic. As expected with Mechanical Turk samples, our subjects are more liberal, better educated, and younger than the adult population. For the purpose of the biasedness of our experimental estimates, however, none of the pretreatment covariates are related to the pattern of correction exposure. The $\chi^{2}$ results are themselves all insignificant at conventional levels.

First, we model effects on factual beliefs using two linear regression models for each correction item, of the following types:

$$
\begin{aligned}
& \text { agreement }_{\mathrm{i}}=\mathrm{b}_{0}+\mathrm{b}_{1}(\text { correction })+\mathrm{e}_{\mathrm{i}} \\
& \text { agreement }_{\mathrm{i}}=\mathrm{b}_{0}+\mathrm{b}_{1}(\text { correction })+\mathrm{b}_{2}(\text { ideology })+\mathrm{b}_{3}(\text { correction } \times \text { ideology })+\mathrm{e}_{\mathrm{i}}
\end{aligned}
$$

where $\mathrm{i}$ indexes issues. For each issue, agreement is measured by a seven-point Likert scale, ranging from "strongly disagree" to "strongly agree." For each item, respondents are asked to agree with the inaccurate position. ${ }^{6}$ The scales are

6 Table 12.2 provides these misstatements, the corrections, and the survey items, for each issue. 
Table 12.3. Experimental balance. The first two columns report the number of subjects by wave and characteristics. The next three columns report the percentage composition of each demographic variable, aggregated according to the number of corrections to which a respondent had been randomly exposed. The final column reports the chi-square test for the corrections seen columns, and the same Cramér's V effect size related to that table. Note: ${ }^{*} \mathrm{p}<0.05$; ${ }^{* *} \mathrm{p}<0.01{ }^{* * *} \mathrm{p}<0.001$

\begin{tabular}{|c|c|c|c|c|c|c|c|}
\hline & & \multicolumn{2}{|c|}{ Subjects } & \multicolumn{3}{|c|}{ Corrections Seen } & \multirow{2}{*}{$\frac{\text { Dependency }}{\mathrm{X}^{2}(V)}$} \\
\hline & & W1 & $\mathrm{W} 2$ & $0-1$ & 2 & $3-4$ & \\
\hline Total & & 1,293 & 1,068 & & & & \\
\hline \multirow{3}{*}{$\begin{array}{l}\text { Presidential } \\
\text { Vote }\end{array}$} & Trump & 405 & 329 & 32 & 31 & 29 & \\
\hline & Clinton & 617 & 519 & 48 & 51 & 46 & $6.34(.05)$ \\
\hline & Other & 271 & 220 & 20 & 18 & 25 & \\
\hline \multirow[t]{3}{*}{ Ideology } & Liberal & 543 & 448 & 41 & 42 & 42 & \\
\hline & Moderate & 526 & 433 & 42 & 40 & 40 & $0.67(.02)$ \\
\hline & Conservative & 224 & 187 & 17 & 18 & 17 & \\
\hline \multirow[t]{3}{*}{ Partisanship } & Democrat & 532 & 437 & 39 & 41 & 42 & \\
\hline & Independent & 524 & 433 & 42 & 38 & 42 & $3.32(.04)$ \\
\hline & Republican & 237 & 198 & 19 & 20 & 16 & \\
\hline \multirow[t]{3}{*}{ Income } & $\$ 5 \mathrm{k}-\$ 35 \mathrm{k}$ & 389 & 316 & 29 & 29 & 30 & \\
\hline & $\$ 35 \mathrm{k}-\$ 85 \mathrm{k}$ & 625 & 522 & 50 & 48 & 49 & $0.9(.02)$ \\
\hline & $>\$ 85 \mathrm{k}$ & 279 & 230 & 21 & 23 & 21 & \\
\hline \multirow[t]{2}{*}{ Gender } & Female & 591 & 485 & 47 & 43 & 47 & \\
\hline & Male & 702 & 583 & 53 & 57 & 53 & \\
\hline \multirow[t]{3}{*}{ Education } & $\begin{array}{l}\text { High School } \\
\text { Diploma or less }\end{array}$ & 147 & 112 & 12 & 8 & 12 & \\
\hline & Some college & 419 & 341 & 30 & 33 & 32 & 4.69. (.05) \\
\hline & $\begin{array}{l}\text { Bachelor's } \\
\text { degree or more }\end{array}$ & 727 & 615 & 58 & 59 & 56 & \\
\hline \multirow[t]{3}{*}{ Age } & $18-34$ & 687 & 553 & 54 & 52 & 51 & \\
\hline & $35-54$ & 454 & 382 & 34 & 38 & 36 & $2.19(.03)$ \\
\hline & $55+$ & 147 & 128 & 13 & 11 & 13 & \\
\hline
\end{tabular}




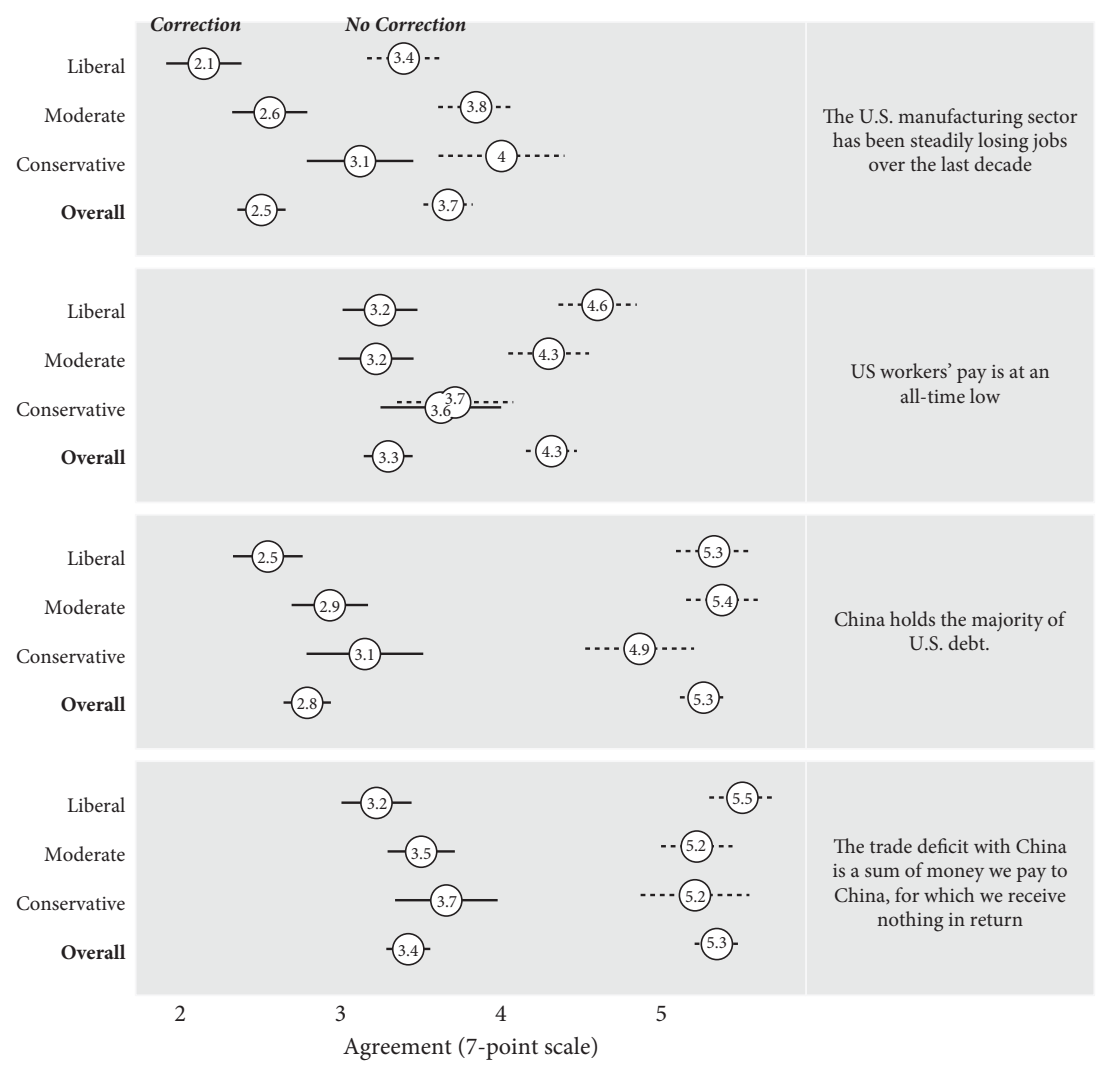

Figure 12.2. Fitted values for regression models measuring effects on factual beliefs. Each point range reports the fitted value, and the associated $95 \%$ confidence interval. Inside each point, the fitted value is rounded to one decimal place. Fitted values for subjects who've seen only the misstatement are depicted with solid lines; fitted values for subjects who've seen both a misstatement and a correction are depicted with a dashed line. Each effect is significant at the $p \leqslant 0.01$, except for corrections shown to conservatives on the issue of U.S. workers' wages. These fitted values are drawn from the regression models in Table 12.4.

converted to a seven-point dependent variable for the models. The first model measures an overall correction effect; the correction item is a binary indicator, contrasting agreement between those who saw a misstatement and a correction, to those who only saw the misstatement. The second model interacts this experimental indicator with a three-part ideological indicator. Fitted values from these models are depicted in Figure 12.2. The estimated coefficients for these models are provided in Table 12.4. 
Table 12.4. Regression models for correction effects on factual accuracy. Dependant variable is a seven-point scale of agreement, with larger values indicating improved factual accuracy. Constants terms omitted from table. These regression models provide the fitted values depicted in Figure 12.2.

\begin{tabular}{|c|c|c|c|c|c|c|c|c|}
\hline \multirow[b]{2}{*}{ Correction } & \multicolumn{2}{|c|}{ China holds debt } & \multicolumn{2}{|c|}{$\begin{array}{l}\text { Manufacturing jobs } \\
\text { decline }\end{array}$} & \multicolumn{2}{|c|}{ Trade deficit wasted } & \multicolumn{2}{|c|}{ U.S. wages lower } \\
\hline & $\begin{array}{c}-2.47^{\star * *} \\
(.11)\end{array}$ & $\begin{array}{c}-2.78^{\star * *} \\
(.16)\end{array}$ & $\begin{array}{c}-1.92^{\star * *} \\
(.10)\end{array}$ & $\begin{array}{l}-2.28^{\star * *} \\
(.15)\end{array}$ & $\begin{array}{c}-1.16^{\star * *} \\
(.11)\end{array}$ & $\begin{array}{l}-1.24^{\star * *} \\
(.17)\end{array}$ & $\begin{array}{c}-1.02^{\star * *} \\
(.11)\end{array}$ & $\begin{array}{l}-1.35^{\star * *} \\
(.17)\end{array}$ \\
\hline Ideology Moderate & & $\begin{array}{c}.05 \\
(.17)\end{array}$ & & $\begin{array}{l}-.28 \\
(.15)\end{array}$ & & $\begin{array}{l}.45^{\star *} \\
(.17)\end{array}$ & & $\begin{array}{l}-.30 \\
(.18)\end{array}$ \\
\hline Ideology Conservative & & $\begin{array}{l}-.46^{* *} \\
(.21)\end{array}$ & & $\begin{array}{l}-.30 \\
(.20)\end{array}$ & & $\begin{array}{l}.61^{* *} \\
(.23)\end{array}$ & & $\begin{array}{l}-.89^{* * *} \\
(.22)\end{array}$ \\
\hline $\begin{array}{l}\text { Number of corrections } \mathrm{x} \\
\text { Moderate }\end{array}$ & & $\begin{array}{l}.34 \\
(.23)\end{array}$ & & $\begin{array}{l}.56^{*} \\
(.22)\end{array}$ & & $\begin{array}{l}-.04 \\
(.24)\end{array}$ & & $\begin{array}{l}.28 \\
(.25)\end{array}$ \\
\hline $\begin{array}{l}\text { Number of corrections } \mathrm{x} \\
\text { Conservative }\end{array}$ & & $\begin{array}{l}1.07^{* * *} \\
(.30)\end{array}$ & & $\begin{array}{l}.73^{* *} \\
(.28)\end{array}$ & & $\begin{array}{l}.36 \\
(.31)\end{array}$ & & $\begin{array}{l}1.27^{* * *} \\
(.32)\end{array}$ \\
\hline Observations & $\begin{array}{r}1,069 \\
.34\end{array}$ & .35 & $\begin{array}{r}1,069 \\
.26\end{array}$ & $\begin{array}{c}1,069 \\
.27\end{array}$ & $\begin{array}{r}1,069 \\
.10\end{array}$ & $\begin{array}{r}1,069 \\
.12\end{array}$ & $\begin{array}{r}1,069 \\
.07\end{array}$ & $\begin{array}{r}1,069 \\
.09\end{array}$ \\
\hline
\end{tabular}


Figure 12.2 shows that accuracy is highly responsive to corrections. On the seven-point scale, effects ranged between 1 and 2.5 points. Again, as noted above, these improvements in accuracy also can be thought of as increases in agreement with the fact-check. Those areas of trade-related misstatements that have the highest level of agreement among uncorrected respondents (specifically, that China holds the majority of U.S. debt, and that the Chinese trade deficit is a sum paid to China for which nothing is received in return), are also the misstatements that prove most correctable. Items where uncorrected respondents express lower agreement (changes in the employment levels in the U.S. manufacturing sector, and changes in the pay levels for U.S. workers) still see large accuracy increases.

Effects are large and well-measured when we consider ideology. Crossing the four misstatements with the three ideological cohorts, only one of these twelve comparisons features an insignificant effect (specifically, among conservatives who saw a correction to claims that U.S. workers' pay is at an all-time low). Speculatively, President Trump's decision to make a populist criticism of legacy U.S. trade policy a cornerstone of his political agenda might have caused respondents to counterargue these politically unwelcome criticisms.

Next, we examine the role of corrections in affecting attitudes. Reflecting the fact that the attitude questions are only obliquely related to the corrections, we measure the intervention as a count (discarding information about the specific corrections a respondent might have seen). This count variable is used to model agreement, with each attitude measured as a dichotomous dependent variable, with a 1 indicating a respondent holds a positive impression of free trade.

$$
\begin{aligned}
\text { policy support }_{i}= & b_{0}+b_{1}(\text { count of corrections })+e_{i} \\
\text { policy support }_{i}= & b_{0}+b_{1}(\text { count of corrections })+b_{2}(\text { ideology })+ \\
& b_{3}(\text { count of corrections } \times \text { ideology })+e_{i}
\end{aligned}
$$

The first equation above measures the effect of the count of corrections on support for each attitude (the separate attitudes are indexed by i). The second equation tests how the relationship between correction exposure and attitudes differ according to respondents' ideology. Table 12.5 reports the coefficients for these models. Figure 12.3 reports the fitted probability drawn from these models.

Figure 12.3 reveals that subjects reliably moved their trade attitudes toward greater support for free trade. These effects are of a meaningful magnitude. Subjects exposed to four corrections were sixteen percentage points more likely to express support for free trade (averaging over the six separate trade policies), compared to the average respondent who saw no corrections. Moreover, unlike other research that finds respondents might accede to unwelcome factual interventions, but compensate by adopting a set of attitudes against 
Table 12.5. Regression models for corrections effect on policy attitudes. The key experimental quantity is the number of factual corrections to which a respondent was exposed. Dependent quantity is a binary indicator of policy agreement. These linear probability models provide the quantities underpinning the estimates in Figure 12.2.

\begin{tabular}{|c|c|c|c|c|c|c|c|c|c|c|c|c|c|c|}
\hline \multirow[b]{2}{*}{$\begin{array}{l}\text { Number } \\
\text { corrections }\end{array}$} & \multicolumn{2}{|l|}{ Overall } & \multicolumn{2}{|c|}{$\begin{array}{l}\text { Trade } \\
\text { agreements are } \\
\text { good }\end{array}$} & \multicolumn{2}{|c|}{$\begin{array}{l}\text { Trade } \\
\text { agreements } \\
\text { create jobs }\end{array}$} & \multicolumn{2}{|c|}{$\begin{array}{l}\text { Trade } \\
\text { agreements } \\
\text { grow economy }\end{array}$} & \multicolumn{2}{|c|}{$\begin{array}{l}\text { Trade } \\
\text { agreements } \\
\text { help families }\end{array}$} & \multicolumn{2}{|c|}{$\begin{array}{l}\text { Trade } \\
\text { agreements } \\
\text { decrease prices }\end{array}$} & \multicolumn{2}{|c|}{$\begin{array}{l}\text { Trade } \\
\text { agreements } \\
\text { increase Wages }\end{array}$} \\
\hline & $\begin{array}{l}.04^{* * *} \\
(.01)\end{array}$ & $\begin{array}{l}.06^{\star * *} \\
(.01)\end{array}$ & $\begin{array}{l}.06^{\star * *} \\
(.02)\end{array}$ & $\begin{array}{l}.09^{* * *} \\
(.02)\end{array}$ & $\begin{array}{l}03 \\
(.01)\end{array}$ & $\begin{array}{l}.08^{\star * *} \\
(.02)\end{array}$ & $\begin{array}{r}.04^{*} \\
(.02)\end{array}$ & $\begin{array}{l}.06^{*} \\
(.03)\end{array}$ & $\begin{array}{l}.06^{\star * *} \\
(.02)\end{array}$ & $\begin{array}{l}.09^{* * *} \\
(.02)\end{array}$ & $\begin{array}{c}.03 \\
(.01)\end{array}$ & $\begin{array}{c}.02 \\
(.02)\end{array}$ & $\begin{array}{c}.01 \\
(.01)\end{array}$ & $\begin{array}{c}.02 \\
(.02)\end{array}$ \\
\hline Moderate & & $\begin{array}{l}-.01 \\
(.03)\end{array}$ & & $\begin{array}{l}-.01 \\
(.07)\end{array}$ & & $\begin{array}{l}-.05 \\
(.07)\end{array}$ & & $\begin{array}{c}-.005 \\
(.08)\end{array}$ & & $\begin{array}{l}.01 \\
(.08)\end{array}$ & & $\begin{array}{l}-.06 \\
(.07)\end{array}$ & & $\begin{array}{l}-.03 \\
(.06)\end{array}$ \\
\hline Conservative & & $\begin{array}{c}.01 \\
(.04)\end{array}$ & & $\begin{array}{l}-.04 \\
(.10)\end{array}$ & & $\begin{array}{c}.21^{*} \\
(.09)\end{array}$ & & $\begin{array}{l}-.04 \\
(.11)\end{array}$ & & $\begin{array}{l}-.05 \\
(.11)\end{array}$ & & $\begin{array}{c}-.22^{*} \\
(.10)\end{array}$ & & $\begin{array}{c}.20^{*} \\
(.08)\end{array}$ \\
\hline $\begin{array}{l}\text { Moderate } \mathrm{x} \\
\text { Number of } \\
\text { corrections }\end{array}$ & & $\begin{array}{c}-.03^{*} \\
(.01)\end{array}$ & & $\begin{array}{l}-.03 \\
(.03)\end{array}$ & & $\begin{array}{l}-.08^{\star *} \\
(.03)\end{array}$ & & $\begin{array}{l}-.02 \\
(.04)\end{array}$ & & $\begin{array}{l}-.05 \\
(.03)\end{array}$ & & $\begin{array}{l}-.01 \\
(.03)\end{array}$ & & $\begin{array}{c}.01 \\
(.03)\end{array}$ \\
\hline $\begin{array}{l}\text { Conservative } \\
\mathrm{x} \text { Number of } \\
\text { corrections }\end{array}$ & & $\begin{array}{l}-.06^{* *} \\
(.02)\end{array}$ & & $\begin{array}{l}-.09^{\star} \\
(.04)\end{array}$ & & $\begin{array}{l}-.13^{\star *} \\
(.04)\end{array}$ & & $\begin{array}{l}-.06 \\
(.05)\end{array}$ & & $\begin{array}{l}-.06 \\
(.05)\end{array}$ & & $\begin{array}{l}-.05 \\
(.04)\end{array}$ & & $\begin{array}{c}-.07^{\star} \\
(.03)\end{array}$ \\
\hline Observations & 5,573 & 5,573 & 857 & 857 & 952 & 952 & 904 & 904 & 958 & 958 & 969 & 969 & 933 & 933 \\
\hline $\mathrm{R}^{2}$ & .01 & .02 & .02 & .05 & .003 & .03 & .01 & .02 & .01 & .03 & .004 & .01 & .001 & .01 \\
\hline
\end{tabular}

Note: ${ }^{*} \mathrm{P}<0.05 ;{ }^{* *} \mathrm{P}<0.01 ;{ }^{* * *} \mathrm{P}<0.001$ 


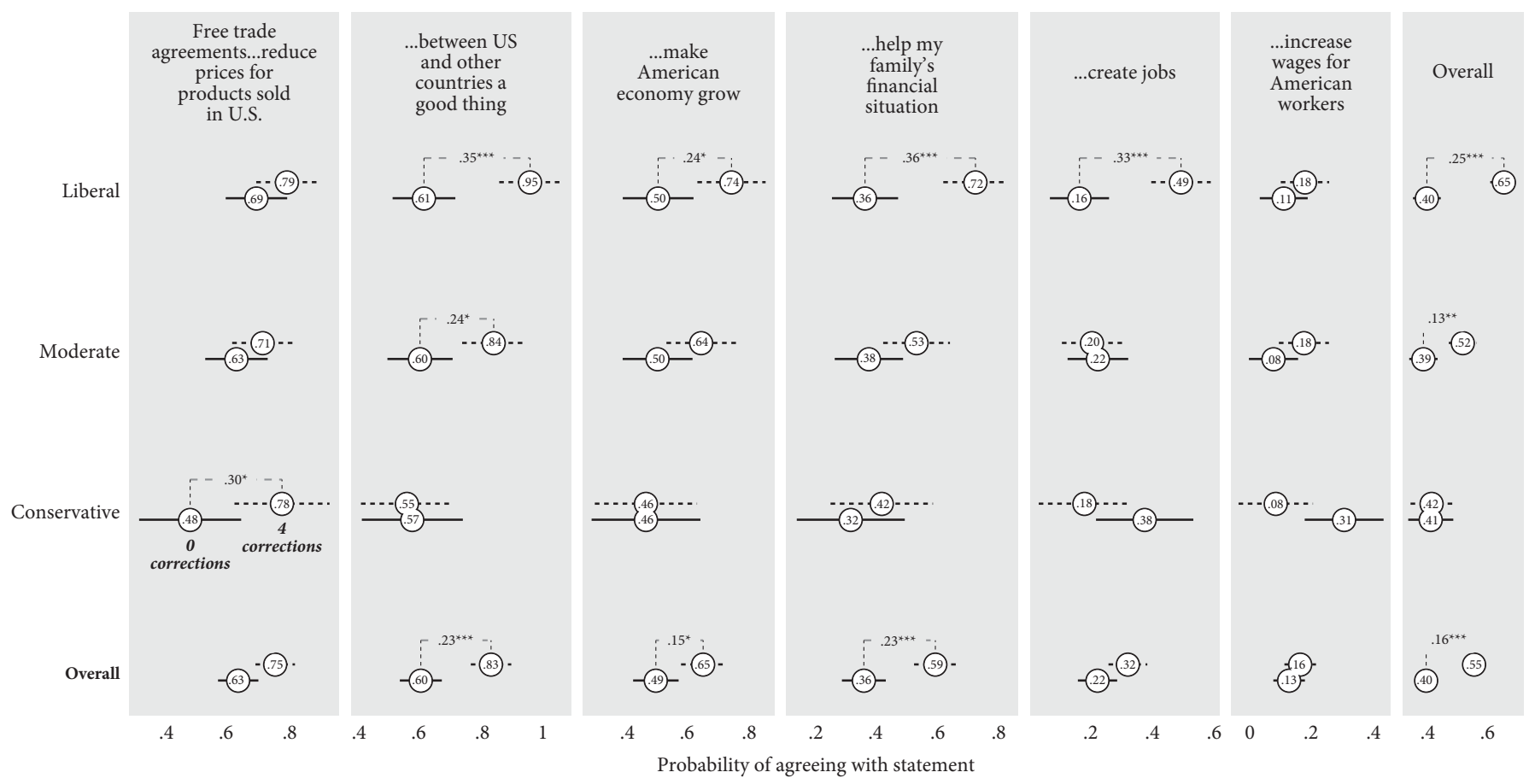

Figure 12.3. Fitted values and pairwise comparison for regression models measuring attitude effects as a function of correction exposure, overall and by ideology. Each point range reports the fitted probability of agreeing with the faceted trade attitude, and their associated $95 \%$ confidence interval, as a function of the number of corrections seen. Solid point ranges show the fitted probability among respondents who saw no corrections. Dashed point ranges report the fitted probability among respondents who saw four corrections. Inside each point, the fitted probability is rounded to two decimal places. Between each fitted probability, we label the size and the significance of the pairwise comparison between zero and four corrections. We label all those pairwise comparison significant at the $\mathrm{p}<0.05$ level. These fitted values are drawn from the regressions in Table 12.4. The full text of each survey item is provided in Table 12.3. Note: ${ }^{*} \mathrm{p}<0.05 ;{ }^{* *} \mathrm{p}<0.01 ;{ }^{* * *} \mathrm{p}<0.001$ 
the implications of these factual claims (e.g., Thorson 2016), in no case did respondents move significantly against trade as a result of corrections.

One important concern relates to the composition of the Pew trade attitudes battery. Several of the Pew attitude battery items have a factual component that may complicate our inferences about the relationship between facts and attitudes. The effects we observe could be a result of the information conveyed by these ostensibly attitudinal items. Only one item on the attitudes battery, which queries subjects about whether trade is a "good or bad thing," is devoid of all plausibly informational content. Fortunately, as Figure 12.3 shows, among all items on the battery, we observed the second-largest effect on this purely attitudinal item. Figure 12.4 and Table 12.6 further supports this conclusion. When we re-estimate the effects on the battery six times, each time subtracting one item from the overall battery, we see that effects remain comparable when any one item is removed-underlining that these effects are likely not attributable to the factual content conveyed by any attitude items.

\section{Discussion and Conclusion}

Relying on a straightforward design similar to that used in other studies of corrections, we observe corrections not only increasing accuracy, but changing attitudes. These changes lead respondents to become more supportive of free trade, deviating from the substantive position of the corrected misstatements. Any "belief echoes" we observe are factual belief echoes, not echoes of the initial misstatement. Furthermore, given that our corrections, misstatements, and attitudes focus on free trade, our results indicate that the long-standing interest of trade scholars in the factual accuracy of perceptions about self-interest (e.g., Fordham and Kleinberg 2012; Mansfield and Mutz 2009; Rho and Tomz 2017) is well-founded. Factual accuracy can affect trade attitudes. Indeed, these results indicate that, at least when it comes to trade, the relationship between facts and attitudes may be more important than previously assumed.

It would be a mistake, however, to interpret these results as demonstrating that corrections always, or even usually, affect attitudes. In prior studies, we have found corrections able to increase belief accuracy but yet have no discernible effects on climate-related attitudes (Porter, Wood, and Bahador 2019) and crimerelated attitudes (Nyhan, Porter, Reifler, and Wood 2020). The current work is limited by its focus on trade, precluding us from speaking on the general capacity of facts to affect attitudes. The technical nature of trade policy, as well as the shifting partisan signals surrounding it, may make it an unusually ripe domain for facts to affect attitudes. Scholars interested in the fact-attitude relationship should investigate a much broader array of policy areas than the present study. 


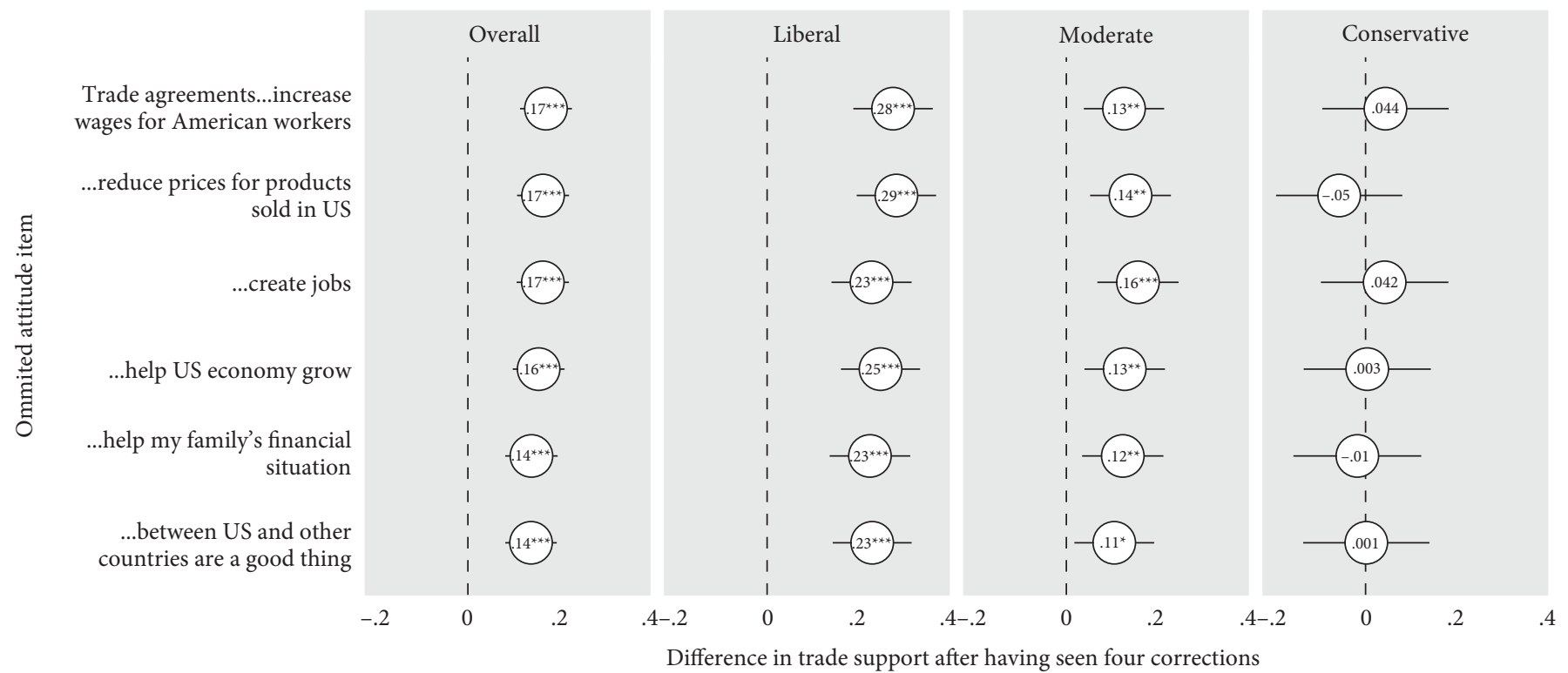

Figure 12.4. Effect of removing attitude items on relationship between correction exposure and trade support. Each point above shows the effect of seeing four corrections, subtracting the fitted value for those who saw only no corrections, on an average trade support, omitting the trade attitude listed on the $y$-axis. Because the dependent variable is measured as a dichotomous indicator, with 1 equaling support for some trade attitude, these estimates can be interpreted as differences in probability. If it were the case that these attitudinal effects were related to some items tapping informational cues, these estimates would be highly variable when certain attitude items were omitted from the average attitude outcome. Estimates are reported overall, and according to respondents' ideology. Fitted values are drawn from the regression models in Table 12.6. The full text of each survey item is provided in Table 12.3. Note: ${ }^{*} \mathrm{p}<0.05 ;{ }^{* *} \mathrm{p}<0.01{ }^{* * *} \mathrm{p}<0.001$ 
Table 12.6. Regression models for omitting attitudinal items to measure consistency of regression estimates. For each model, we omit the labeled attitudinal indicator, and then regress the average support for the remaining policies on either correction exposure or correction exposure interacted with ideology. These regression models provide the correction exposure estimates on trade support depicted

in Figure 12.4.

\begin{tabular}{|c|c|c|c|c|c|c|c|c|c|c|c|c|}
\hline \multirow[b]{2}{*}{ Number corrections } & \multicolumn{2}{|c|}{$\begin{array}{l}\text { Trade agreements } \\
\text { good }\end{array}$} & \multicolumn{2}{|c|}{$\begin{array}{l}\text { Trade agreements } \\
\text { create jobs }\end{array}$} & \multicolumn{2}{|c|}{$\begin{array}{l}\text { Trade agreements } \\
\text { grow economy }\end{array}$} & \multicolumn{2}{|c|}{$\begin{array}{l}\text { Trade agreements } \\
\text { help family }\end{array}$} & \multicolumn{2}{|c|}{$\begin{array}{l}\text { Trade agreements } \\
\text { reduce prices }\end{array}$} & \multicolumn{2}{|c|}{$\begin{array}{l}\text { Trade agreements } \\
\text { increase wages }\end{array}$} \\
\hline & $\begin{array}{l}.03^{* * *} \\
(.01)\end{array}$ & $\begin{array}{l}.06^{\star * *} \\
(.01)\end{array}$ & $\begin{array}{l}.04^{* * *} \\
(.01)\end{array}$ & $\begin{array}{l}.06^{\star * *} \\
(.01)\end{array}$ & $\begin{array}{r}04^{* * *} \\
(.01)\end{array}$ & $\begin{array}{l}.06^{\star * *} \\
(.01)\end{array}$ & $\begin{array}{l}.04^{* * *} \\
(.01)\end{array}$ & $\begin{array}{l}.06^{\star * \star} \\
(.01)\end{array}$ & $\begin{array}{l}.04^{* * *} \\
(.01)\end{array}$ & $\begin{array}{l}.07^{\star * \star} \\
(.01)\end{array}$ & $\begin{array}{l}.04^{* * *} \\
(.01)\end{array}$ & $\begin{array}{l}.07^{\star * *} \\
(.01)\end{array}$ \\
\hline Moderate & & $\begin{array}{l}-.01 \\
(.04)\end{array}$ & & $\begin{array}{l}-.03 \\
(.04)\end{array}$ & & $\begin{array}{l}-.02 \\
(.04)\end{array}$ & & $\begin{array}{l}-.02 \\
(.04)\end{array}$ & & $\begin{array}{l}.0003 \\
(.04)\end{array}$ & & $\begin{array}{l}-.01 \\
(.04)\end{array}$ \\
\hline Conservative & & $\begin{array}{l}.02 \\
(.05)\end{array}$ & & $\begin{array}{l}-.03 \\
(.05)\end{array}$ & & $\begin{array}{l}.02 \\
(.05)\end{array}$ & & $\begin{array}{l}.02 \\
(.05)\end{array}$ & & $\begin{array}{l}.06 \\
(.05)\end{array}$ & & $\begin{array}{l}-.03 \\
(.05)\end{array}$ \\
\hline $\begin{array}{l}\text { Mod. x Number of } \\
\text { corrections }\end{array}$ & & $\begin{array}{l}-.03^{\star} \\
(.02)\end{array}$ & & $\begin{array}{l}-.02 \\
(.02)\end{array}$ & & $\begin{array}{l}-.03 \\
(.02)\end{array}$ & & $\begin{array}{l}-.03 \\
(.02)\end{array}$ & & $\begin{array}{l}-.04^{\star} \\
(.02)\end{array}$ & & $\begin{array}{r}-.04^{\star} \\
(.02)\end{array}$ \\
\hline $\begin{array}{l}\text { Cons x Number of } \\
\text { corrections }\end{array}$ & & $\begin{array}{l}-.06^{* *} \\
(.02)\end{array}$ & & $\begin{array}{r}-.05^{\star} \\
(.02)\end{array}$ & & $\begin{array}{l}-.06^{* *} \\
(.02)\end{array}$ & & $\begin{array}{l}-.06^{* *} \\
(.02)\end{array}$ & & $\begin{array}{l}-.09^{* * *} \\
(.02)\end{array}$ & & $\begin{array}{l}-.06^{* *} \\
(.02)\end{array}$ \\
\hline Observations & 4.716 & 4.716 & 4.621 & 4.621 & 4.669 & 4.669 & 4.615 & 4.615 & 4.604 & 4.604 & 4.640 & 4.640 \\
\hline $\mathrm{R}^{2}$ & .005 & .01 & .01 & .02 & .01 & .02 & .005 & .01 & .01 & .02 & .01 & .02 \\
\hline
\end{tabular}

Note: ${ }^{*} \mathrm{p}<0.05 ;{ }^{* *} \mathrm{p}<0.01 ;{ }^{* * *} \mathrm{p}<0.001$ 
Our study's other limitations suggest additional avenues for research. In focusing on trade-related misstatements advanced by members of both parties, and to clearly measure attitude effects, our misstatements and corrections were both normatively tilted in favor of free trade. Nothing in our results should be understood to imply that only pro-free trade fact-checks will change people's minds about trade. Anti-free trade fact-checks might well reduce attitudinal support for free trade. More broadly, there are many reasons to be skeptical about free trade that our corrections do not capture. For instance, liberalizing trade entails trade-offs for an economy-improved access to imports limits inflation, but may imperil inefficient domestic employers. Our fact-checks do not bring to mind such compromises; if they had, we might have observed more ambivalent attitude effects. To measure whether fact-checks can produce clear attitudinal shifts, we designed the fact-check so as to present subjects with neutral evidence undercutting the earlier misstatement, thereby avoiding complexity and ambiguitybut bringing us closer to common fact-checking practices (Uscinski and Butler 2013). Future research should investigate the possibility that anti-free trade corrections to impressions could depress support for trade and explore whether more ambiguous, albeit less realistic fact-checks can also affect attitudes.

For now, the present results indicate that fact-checks can affect a broader set of outcomes than previously known. If factually accurate information can change attitudes, fact-checking may be able to lead to the kind of evidencebased accountability that democratic theorists have described as one of the best justifications for increased political knowledge (e.g., Delli Carpini and Keeter 1996; Hochschild and Einstein 2015). Future research should study this possibility, by considering how attitude change, in turn, might affect views toward politicians and parties.

But our findings also leave fact-checking with a dilemma. To the extent that fact-checks change attitudes, fact-checkers who aim for neutrality may be inadvertently intervening in democratic outcomes. As others have noted, fact-checking is hardly ever as neutral as it purports to be, often transforming multivalent political debates into overly simplified discussions of truth and falsehood (Uscinski and Butler 2013). Our results corroborate this concern, and map out the possible consequences. In striving to make people more informed, factcheckers may - at least on one issue-also be changing their minds.

\section{Acknowledgments}

We thank David Barker and Elizabeth Suhay for their guidance, Mark McKibbin for helpful research assistance and helpful comments at the Midwest Political Science Association's 2019 meeting. All mistakes are our own. 


\section{References}

Delli, Carpini Michael, and Scott Keeter. 1996. What Americans Know About Politics and Why It Matters. New Haven, CT: Yale University Press.

Fordham, Benjamin O., and Katja B. Kleinberg. 2012. "How Can Economic Interests Influence Support for Free Trade?” International Organization 66 (2):311-328.

Fox News. 2015. "Donald Trump Talks Taxes, Trade, 9/11 and Why He Takes Personal Shots at Political Rivals." https://fxn.ws/2U7cadl

Graves, Lucas. 2016. Deciding What's True: The Rise of Political Fact-Checking in American Journalism. New York: Columbia University Press.

Haglin, Kathryn. 2017. "The Limitations of The Backfire Effect." Research and Politics. https://doi.org/10.1177/2053168017716547

Hochschild, Jennifer, and Katherine L. Einstein. 2015. Do Facts Matter?: Information and Misinformation in American Politics. Norman: University of Oklahoma Press.

Jones, B. 2018. "Americans are generally positive about free trade agreements, more critical of tariff increases." Pew Research Center. May 10, 2018. https:// www.pewresearch.org/fact-tank/2018/05/10/americans-are-generally-positiveabout-free-trade-agreements-more-critical-of-tariff-increases/

Luhby, Tami. 2015. "Trump Says Wages Are Too Low." CNN. https://money.cnn.com/ 2015/12/28/news/economy/trump-wages/

Mansfield, Edward D., and Diana Mutz. 2009. "Support for Free Trade: Self-Interest, Sociotropic Politics and Out-Group Anxiety." International Organization 63 (3): 425-457.

"Major Foreign Holders of Treasury Securities (in billions of dollars) Holdings at End of Period." 2012. U.S. Treasury Department. Downloaded from https:// ticdata.treasury.gov/Publish/mfh.txt

Mutz, Diana, and Eunji Kim. 2017. "The Impact of In-group Favoritism on Trade Preferences.” International Organization 71 (4): 827-850.

Mutz, Diana. 2018. "Status Threat, Not Economic Hardship, Explains the 2016 Presidential Vote." Proceedings of the National Academy of Sciences 115 (19): E4330-E4339.

Nyhan, B., Porter, E., Reifler, J., Wood, T. 2020. “Taking Fact-Checks Literally But Not Seriously? The Effects of Journalistic Fact-Checking on Factual Beliefs and Candidate Favorability." Political Behavior 42, 939-960. https://doi.org/10.1007/ s11109-019-09528-x

Nyhan, Brendan, and Jason Reifler. 2010. "When Corrections Fail." Political Behavior 32 (2): 303-330.

Porter, Ethan, and Thomas J. Wood. 2019. False Alarm: The Truth About Political Mistruths in the Trump Era. New York: Cambridge University Press.

Porter, Ethan, Thomas J. Wood, and Babak Bahador. 2019. "Can Presidential Misinformation on Climate Change Be Corrected?" Research and Politics. https:// doi.org/10.1177/2053168019864784

Porter, Ethan, Thomas J. Wood, and David Kirby. 2018. "Sex Trafficking, Russian Infiltration, Birth Certificates, and Pedophilia: A Survey Experiment Correcting Fake News." Journal of Experimental Political Science 5 (2): 159-164.

Rho, Sungmin, and Michaek Tomz. 2017. "Why Don't Trade Preferences Reflect Economic Self- Interest?” International Organization 71 (S1): S85-S108.

Sanders, Bernie. 2011. The Speech: A Historic Filibuster on Corporate Greed and the Decline of our Middle Class. Pacific Publishing Studio. 
Scheve, Kenneth, and Matthew J. Slaughter. 2001. Globalization and the Perception of American Workers. Washington, DC: Institute for International Economics.

Sides, John, Michael Tesler, and Lynn Vavreck. 2019. Identity Crisis: The 2016 Presidential Campaign and the Battle for the Meaning of America. Princeton, NJ: Princeton University Press.

Thaler, Richard. 1994. Quasi-Rational Economics. New York: Russell Sage Foundation.

Thorson, Emily. 2016. "Belief Echoes: The Persistent Effects of Corrected Misinformation.” Political Communication 33 (3): 460-480.

Uscinski, Joseph, and Ryden W. Butler. 2013. "The Epistemology of Fact Checking." Critical Review 25 (2): 162-180.

United States Bureau of Labor Statistics. 2020. Occupational Employment Statistics, May 2020. National Industry-Specific Occupation Employment and Wage Estimates. https://www.bls.gov/oes/current/oessrci.htm

United States Treasury Department. 2020. Securities (B): Portfolio Holdings of U.S. and Foreign Securities. https://www.treasury.gov/resource-center/data-chart-center/tic/ Pages/ticsec2.aspx

Wood, Thomas J., and Ethan Porter. 2019. “The Elusive Backfire Effect: Mass Attitudes' Steadfast Factual Adherence." Political Behavior 41: 135-163. https://doi.org/10.1007/ s11109-018-9443-y 